\title{
Synthesis of Tetrakisbenzo-31(34)-crown-7(8) Ethers
}

\author{
Truong Hong Hieu, ${ }_{1}{ }^{a, c}$ Nguyen T. T. Phuong, ${ }_{1}$ Anatoly T. Soldatenkov, $_{1}{ }^{e}$ \\ Vasily E. Kotsuba, ${ }^{e}$ Elena I. Polyakova, ${ }^{e}$ Nguyen Van Tuyen, ${ }^{\mathrm{a}, \mathrm{b}}$ Tran T. Thanh Van, ${ }^{\mathrm{d}}$ \\ Dang T. Tuyet Anh, ${ }^{\mathrm{a}, \mathrm{b}}$ and Le Tuan Anh ${ }^{\mathrm{d} @}$
}

\author{
anstitute of Chemistry, Vietnam Academy of Science and Technology, Hanoi, Vietnam \\ ${ }^{\mathrm{b}}$ Graduate University of Science and Technology, Vietnam Academy of Science and Technology, Hanoi, Vietnam \\ ${ }^{c}$ Department of Biotechnology, Vietnam-Russia Tropical Centre, Hanoi, Vietnam \\ ${ }^{\mathrm{d}}$ Faculty of Chemistry, University of Science, Vietnam National University, Hanoi, Vietnam \\ ${ }^{\mathrm{e}} \mathrm{RUDN}$ University, 117198 Moscow, Russia \\ ${ }^{\circledR}$ Corresponding authorE-mail: anhlt.vnu@gmail.com
}

\begin{abstract}
Condensations of 1,5-bis(2-formylphenoxy)-3-oxapentane (1a) or 1,8-bis(2-formylphenoxy)-3,6-dioxanoctane (1b) podands and 1,8-bis(2-acetylphenoxy)-3,6-dioxanoctane (2) gave two novel crown ethers: tetrakis-(benzo)-31-crown-7 ether (5) and tetrakis(benzo)-34-crown-8 ether (6). Their molecular structures were established by IR, NMR and MS methods.
\end{abstract}

Keywords: Tetrakis(benzo)-31-crown-7 ether, tetrakis(benzo)-34-crown-8 ether, Petrenko-Kritchenko reaction, diketon, dialdehyde.

\section{Синтез тетрабензо-31(34)-краун-7(8) эфиров}

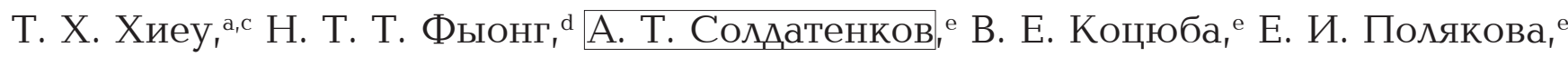 \\ H. B. Туен, ${ }^{a, b}$ T. T. T. Baн, ${ }^{d}$ A. T. T. Ань, ${ }^{a, b}$ ᄉ. T. Ань ${ }^{d @}$
}

${ }^{\mathrm{a}}$ Институт химии, Вьетнамская академия науки и технологии, Ханой, Вьетнам

${ }^{\mathrm{b}}$ Высший университет науки и техники, Вьетнамская академия наук и технологии, Ханой, Вьетнам

' Факультет биотехнологии, Российско-Вьетнамский Тропический ичентр, Ханой, Вьетнам

${ }^{\mathrm{d}}$ Факультет химии, Университет науки, Вьетнамский наичональный университет, Ханой, Вьетнам

еРоссийский университет дружбь народов, 117198 Москва, Россия

@E-mail: anhlt.vnu@gmail.com

\begin{abstract}
Конденсация подандов, 1,5-бис(2-формилфенокси)-3-оксапентана (1a) или 1,8-бис-(2-формилфенокси)-3,6диоксаноктана (1b), с 1,8-бис(2-ацетилфенокси)-3,6-диоксаноктаном (2) привела к образованию двух новых краун-эфиров - тетракис(бензо)-31-краун-7 эфира (5) и тетракис(бензо)-34-краун-8 эфира (6). Их молекулярная структура была подтверждена методами ИК, ЯМР спектроскопии и масс-спектрометрии.
\end{abstract}

Ключевые слова: Тетракис(бензо)-31-краун-7 эфир, тетракис(бензо)-34-краун-8 эфир, реакция ПетренкоКриченко, дикетон, диальдегид. 
In the previous publications, ${ }^{[1,2,3]}$ we have reported on the preparations of dibenzo[ $\gamma$-(aryl)pyrido]aza-14-crown-4 ethers from arylaldehyde, 1,5-bis(2-acetylphenoxy)-3oxapentane and ammonium acetate by Petrenko-Kritchenko reaction. These new compounds containing $\gamma$-phenylpyridine ring exhibited cytotoxicity to several cancer cell lines: Hepatocellular carcinoma (Hep-G2); Rhabdosarcoma (RD), Human Uterine (FL); Human Breast adenocarcinoma (MCF7). ${ }^{[1,3]}$ In addition, using the similar domino reaction for synthesis of new azacrown ether, we have obtained a macroheterocyclic system containing two azacrown ether fragments. ${ }^{[4]}$

With the aim of preparing ditopic systems $(\mathbf{3 a}, \mathbf{b})$, we have studied condensation of bis(2-formylphenoxy)-3,6-dioxaoctane (1a) or bis(2-formylphenoxy)-3-oxapentane (1b) with bis(2-acetylphenoxy)-3-oxapentane and ammonium acetate. However, instead of the expected azacrown systems $(\mathbf{3 a}, \mathbf{b})$ the tetrakis(benzo)crown ethers $(\mathbf{4 a}, \mathbf{b})$ were isolated by column chromatography with the low yield $(20-28 \%) .^{[5,6]}$

The structure of $(\mathbf{4 a}, \mathbf{b})$ were determined by IR, NMR, MS and X-ray analysis. The volume of internal cavity of macrocycle (4b) is equal to $125 \AA^{3}$. The dihedral angles between the benzene planes of $\mathrm{C} 1, \mathrm{C} 43-\mathrm{C} 47 / \mathrm{C} 5-\mathrm{C} 10$, $\mathrm{C} 5-\mathrm{C} 10 / \mathrm{C} 18-\mathrm{C} 23, \mathrm{C} 18-\mathrm{C} 23 / \mathrm{C} 27-\mathrm{C} 32$ and $\mathrm{C} 27-\mathrm{C} 32 / \mathrm{C} 1, \mathrm{C} 43-$ $\mathrm{C} 47$ are $64.91(8), 65.14(8), 61.64(8)$ and $56.67(9)^{\circ}$, respectively. ${ }^{[5,6]}$

To optimize the reaction and continue developing of novel tetrakis(benzo)crown ethers, the similar condensations of two dialdehydes (1a,b) with diketones (2) without ammonium acetate were studied. The reaction was stirred in system $\mathrm{K}_{2} \mathrm{CO}_{3} / \mathrm{H}_{2} \mathrm{O} / \mathrm{C}_{2} \mathrm{H}_{5} \mathrm{OH}$ for $3 \mathrm{~h}$ at $50{ }^{\circ} \mathrm{C}$. The formed yellow wax-like precipitate was separated and recrystallized from ethanol. Macroheterocycles 31-crown-7 ethers (5) and 34-crown-8 ether (6) were obtained in good yields (up to $88 \%)$.

The structure of compounds $(\mathbf{5}, \mathbf{6})$ was determined by NMR, IR spectrometry and MS spectrometry. Thus, in the ${ }^{1} \mathrm{H}$ NMR spectra of macroheterocycle tetrakis(benzo)31crown-7 ether (5) the signals of sixteen aromatic proton appeared in the region $\delta 6.85-7.54 \mathrm{ppm}$ and four vinylketone protons $(\mathrm{CH}=\mathrm{CH}-\mathrm{C}=\mathrm{O})$ were observed in the weak field at $\delta$ $7.60 \mathrm{ppm}$ and $\delta 7.78 \mathrm{ppm}$ as two doublets $(2 \mathrm{H}$ of each: $\mathrm{H}-2$, $\mathrm{H}-3$ and H-28, H-29). Spin-spin coupling constant ${ }^{3} J$ of

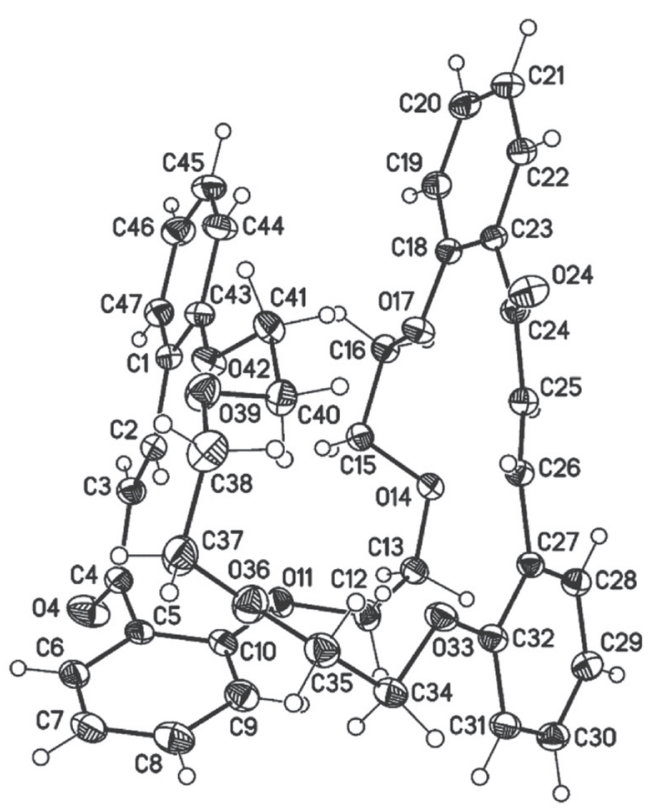

Figure 1. General view and crystallographic numeration of compound (4b) according to X-ray study data.

ethylene protons is equal to $16.5 \mathrm{~Hz}$ in both cases, which indicated the trans-position of $-\mathrm{Ph}$ and $-(\mathrm{C}=\mathrm{O})-\mathrm{Ph}$ substituents. Signals from the polyether groups $\left(-\mathrm{CH}_{2} \mathrm{O}-\right)$ appeared as four multiplets in the region $\delta 3.54-4.17 \mathrm{ppm}$. The ${ }^{13} \mathrm{C}$ NMR spectra show many pairs of symmetric carbon atoms. All methylene carbon appear in the region of $\delta 68.65,68.73$, 69.27, 70.01, $70.70 \mathrm{ppm}$, and $\mathrm{C}_{\text {carbonyl }}(\mathrm{C} 4, \mathrm{C} 27)$ is observed at $194.46 \mathrm{ppm}$. Its IR spectrum displays absorption bands at $1643 \mathrm{~cm}^{-1}$ which is characteristic for $\mathrm{C}=\mathrm{O}$ bonds. HPLC-MS (ESI) gave a clear $[\mathrm{M}+\mathrm{Na}]^{+}$peak at 687.25671 which agrees with the overall molecular formula of 31-crown-7 ether (5). Compound (6) is a 34-membered crownophane with the vinylketone protons resonate in the weak field at $\delta 7.36$ and $7.88 \mathrm{ppm}$ with the spin-spin coupling constant ${ }^{3} J=16.0 \mathrm{~Hz}$ in both cases. All the signals of aromatic proton appear in the region $\delta 6.80-7.56 \mathrm{ppm}$ and the signals of twenty four methylene protons $\left(-\mathrm{CH}_{2} \mathrm{O}-\right)$ overlap each other and give rise to six multiplets in the region of $\delta 3.26-4.13 \mathrm{ppm}$. The<smiles>CC(=O)c1ccccc1OCCOCCOc1ccccc1C=O</smiles>

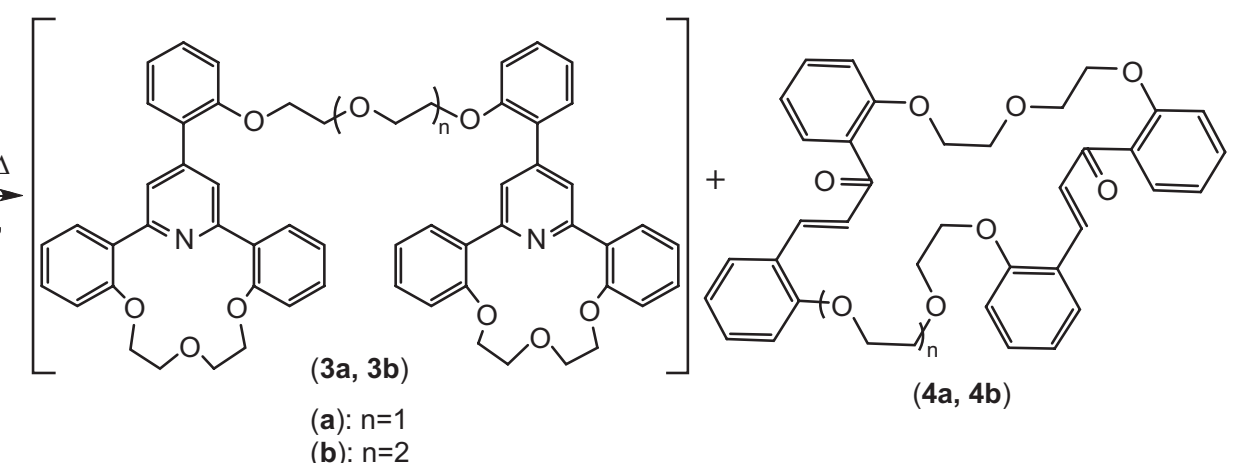

$(1 \mathrm{a}, \mathrm{b})$

Scheme 1. Synthesis of non-nitrogenous macroheterocycles under the Petrenko-Kritchenko conditions. 
<smiles>O=Cc1ccccc1OCCOCCOCCO</smiles>

(a): $n=1 ;(\mathbf{b}): n=2$

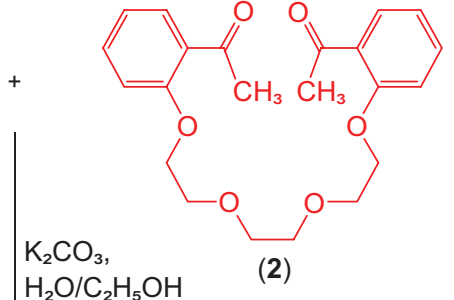

$\mathrm{H}_{2} \mathrm{O} / \mathrm{C}_{2} \mathrm{H}_{5} \mathrm{OH}$
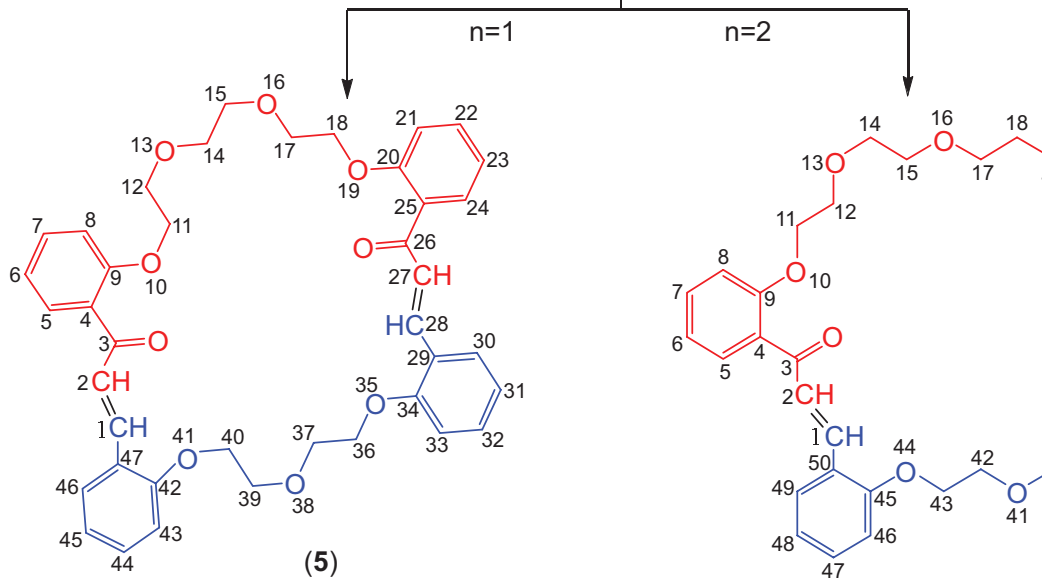<smiles>C=CC(=O)c1ccccc1OC</smiles><smiles>COc1ccccc1C(=O)/C=C/[C@H]1CC=CCC1OCCOCCO[B]COc1ccccc1</smiles>

Scheme 2. Synthesis of tetrakis(benzo)-31-crown-7 ether and tetrakis(benzo)-34-crown-8 ether.

IR absorption band near $1654 \mathrm{~cm}^{-1}$ confirmed the presence of $\mathrm{C}=\mathrm{O}$ functional groups. The structure of compound (6) was further supported by its LC-MS spectra (ESI), indicating the clear $[\mathrm{M}+\mathrm{H}]^{+}$ion peak at $m / z$ 709.2.

All of non-nitrogenous macroheterocycles $(\mathbf{4 a}, \mathbf{b}, \mathbf{5}, \mathbf{6})$ are interesting as effective complexing ligands in the coordination chemistry.

\section{Experimental}

Melting points were determined using a Raga melting point apparatus. IR spectra were recorded on Shimadzu FT IR PC (S) 8201 spectrometer by using $\mathrm{KBr}$ pellets and the absorption frequencies are expressed in reciprocal centimeters $\left(\mathrm{cm}^{-1}\right)$. NMR spectra was taken on BRUKER $500 \mathrm{MHz}$ spectrometer using TMS as an internal reference. The chemical shifts were expressed in parts per million (ppm). ESI-MS were recorded in LTQ orbitrap XL mass spectrometer, Thermo Scientific Company

(2E, 28E)-11,14,17,20,36,39,42-Heptaoxapentacyclo[41.4.0.0 $\left.0^{5,10} \cdot 0^{21,26} \cdot 0^{30,35}\right]$-heptatetraconta-1(43), 2, 5(10), 6, 8, 21,23,25,28,30,32,34,44,46-tetradecaen-2,28-dione (5). A solution of 1,5-bis(2-formylphenoxy)-3-oxapentane (1a) $(0.41 \mathrm{~g}, 1.30 \mathrm{mmol})$ in ethanol $(10 \mathrm{ml})$ and a solution of 1,8-bis(2-acetylphenoxy)-3,6dioxanoctane $(2)(0.50 \mathrm{~g}, 1.30 \mathrm{mmol})$ in ethanol $(10 \mathrm{ml})$ were added simultaneously to a suspension of $\mathrm{K}_{2} \mathrm{CO}_{3}(5.0 \mathrm{~g}, 36 \mathrm{mmol})$ in $30 \mathrm{ml}$ water/ethanol (1:1). The reaction mixture was magnetically stirred at $50{ }^{\circ} \mathrm{C}$ for 3 days. The formed precipitate was filtered off, washed with ethanol and chromatographically purified on silica gel (eluating with hexane-ethylacetate, 2:1). Compound (5) was obtained as $0.74 \mathrm{~g}$ light-yellow crystals $(85.0 \%) . \mathrm{R}_{\mathrm{f}}=0.64$ ( $n$-hexane/EtOAc, 1:1). M.p. $126-128{ }^{\circ} \mathrm{C}$. IR (KBr) $v \mathrm{~cm}^{-1}: 2920,2870,1643,1599$, 1485. ${ }^{1} \mathrm{H}$ NMR $\left(\mathrm{CDCl}_{3}, 500 \mathrm{MHz}, 300 \mathrm{~K}\right) \delta_{\mathrm{H}} \mathrm{ppm:} \mathrm{3.54,} \mathrm{3.88,} 4.00$ and 4.17 (all m, 6H, 5H, 5H and $4 \mathrm{H}$, respectively, $-\mathrm{CH}_{2} \mathrm{CH}_{2} \mathrm{O}-$ ); 6.85-7.54 (16H, m, H $), 7.60$ and 7.78 (both d, $2 \mathrm{H}$ each, $\mathrm{O}=\mathrm{C}-$ $\left.\mathrm{CH}_{\text {trans }}=\mathrm{CH}, J=16.5 \mathrm{~Hz}\right) \cdot{ }^{13} \mathrm{C} \mathrm{NMR}\left(\mathrm{CDCl}_{3}, 125 \mathrm{MHz}, 300 \mathrm{~K}\right) \delta_{\mathrm{C}}$ ppm: 68.65 (C38, C40), 68.73 (C13, 18), 69.27 (C15, C16), 70.01 (C12, C19), 70.70 (C37, C41),112.75 (C34, C44), 112.79 (C9, C22), 120.93 (C7, C24), 121.10 (C46, C32), 124.44 (C3, C28), 128.63 (C6, C25), 129.44 (C1, C30), 130.01 (C33, C45), 130.17 (C5, C26), 131.43 (C31, C47), 132.27 (C8, C23), 139.30 (C2, C29), 157.10 (C35, C43), 157.97 (C10, C21), 194.46 (C4, C27). HRMS calcd. for $\mathrm{C}_{40} \mathrm{H}_{40} \mathrm{NaO}_{9}[\mathrm{M}+\mathrm{Na}]^{+}: 687.25700$, found: 687.25671 .

$(2 E, 28 E)-11,14,17,20,36,39,42,45$-Octaoxapentacyclo[41.4.0.0 $\left.0^{5,10} \cdot 0^{21,26} \cdot 0^{30,35}\right]$-pentaconta-1(46), 2, 5(10), 6, 8, 21,23, 25,28,30,32,34,47,49-tetradecaen-2,28-dione (6). A solution of 1,8-bis(2-formylphenoxy)-3,6-dioxanoctane (1b) (0.41 g, $1.30 \mathrm{mmol})$ in ethanol $(10 \mathrm{ml})$ and a solution of 1,8-bis(2acetylphenoxy)-3,6-dioxanoctane (2) (0.46 g, $1.30 \mathrm{mmol})$ in ethanol $(10 \mathrm{ml})$ were added simultaneously to a suspension of $\mathrm{K}_{2} \mathrm{CO}_{3}(5.0 \mathrm{~g}$, $36 \mathrm{mmol})$ in $30 \mathrm{ml}$ water/ethanol (1:1). The reaction mixture was magnetically stirred at $50{ }^{\circ} \mathrm{C}$ for 3 days. The formed precipitate was filtered off, washed with ethanol and chromatographically purified on silica gel (eluating with hexane-ethylacetate, 2:1). Compound (6) was obtained as light-yellow crystals $(0.74 \mathrm{~g}, 1.11 \mathrm{mmol}, 88.0 \%)$. $\mathrm{R}_{\mathrm{f}}=0.51$ ( $n$-hexane/EtOAc, $\left.1: 1\right)$. M.p. $174-176^{\circ} \mathrm{C}$. IR $(\mathrm{KBr}) \vee \mathrm{cm}^{-1}$ : 2932, 2872, 1655, 1599, 1485. ${ }^{1} \mathrm{H}$ NMR $\left(\mathrm{CDCl}_{3}, 500 \mathrm{MHz}, 300 \mathrm{~K}\right)$ $\delta_{\mathrm{H}}$ ppm: $3.26,3.57,3.64,3.87,4.03$ and 4.13 (all m, 4H each, respectively, $\left.-\mathrm{CH}_{2} \mathrm{CH}_{2} \mathrm{O}-\right) ; 6.80-7.56\left(16 \mathrm{H}, \mathrm{H}_{\text {arom }}\right), 7.36$ and 7.89 (both d, $2 \mathrm{H}$ each, $\left.\mathrm{O}=\mathrm{C}-\mathrm{CH}_{\text {trans }}=\mathrm{CH}, J=16.0 \mathrm{~Hz}\right) .{ }^{13} \mathrm{C} \mathrm{NMR}\left(\mathrm{CDCl}_{3}\right.$, $125 \mathrm{MHz}, 300 \mathrm{~K}) \delta_{\mathrm{C}}$ ppm: 68.33, 68.51, 69.34, 69.73, 70.67, 71.11, $112.46,112.79,120.87,120.92,124.26,127.95,128.73,130.13$, $130.17,131.45,132.47,138.61,157.17,157.94,193.87 . \mathrm{MS}(\mathrm{m} / \mathrm{z})$ : $709.2[\mathrm{M}+\mathrm{H}]^{+}$. Found (\%): C 71.29; H 6.17. $\mathrm{C}_{42} \mathrm{H}_{44} \mathrm{O}_{10}$ requires $(\%)$ : C 71.17; H 6.26.

In conclusion, two novel crown ethers, tetrakis(benzo)31-crown-7 ether (5) and tetrakis(benzo)-34-crown-8 ether (6), were successfully synthesized by condensation reaction of podands 1,5-bis(2-formylphenoxy)-3-oxapentane (1a), 1,8-bis(2-formylphenoxy)-3,6-dioxanoctane (1b) and 1,8-bis(2-acetylphenoxy)-3,6-dioxanoctane (2). The molecular structures of non-nitrogenous macroheterocycles were 
established by IR, NMR, and MS. Both of them are interesting as effective complexing ligands in the coordination chemistry.

Acknowledgements. This research is funded by Vietnam Naitonal Foundation for Science and Technology Development (NAFOSTED) under grant number 104.01-2014.39.

\section{References}

1. Le T.A., Truong H.H., Thi T.P.N., Thi N.D., To H.T., Thi H.P. Soldatenkov A.T. Mendeleev Commun. 2014, 25, 224-225.
2. Le T.A., Truong H.H., Nguyen T.T.Ph., Tran T.T.V., Dao T.N., Soldatenkov A.T. Vietnam Journal of Chemistry 2015, 53(4E1), 141-144.

3. Le A.T., Truong H.H., Nguyen Ph.T.T., Pham H.T., Kotsuba V.E., Soldatenkov A.T., Khrustalev V.N., Wodajo A.T. Macroheterocycles 2014, 7, 386-390.

4. Truong H.H., Le T.A., Soldatenkov A.T., Golovtsov N.I., Soldatova S.A. Chem. Heterocycl. Compd. 2012, 47, 13171318.

5. Le T.A., Truong H.H., Soldatenkov A.T., Soldatova S.A., Khrustalev V.N. Acta Cryst. E. 2011, E67, 1128-1129.

6. Le T.A., Truong H.H., Nguyen T.T.Ph., Dao T.N., Tran T.T.V., Soldatenkov A.T. Vietnam Journal of Chemistry 2015 , 53(4E2), 153-155. 